\title{
Contratação Emergencial e Desídia Administrativa
}

\section{Marinês Restelatto Dotti}

\section{INTRODUÇÃO}

Toda atividade administrativa do Estado é norteada pelos princípios da supremacia e da indisponibilidade do interesse público. O fim, e não a vontade, domina todas as formas de administração. Para realizar suas funções, a Administração Pública recorre freqüentemente à colaboração de terceiros. O recurso da Administração às atvidades e aos bens privados manifestase sob modalidades diversas, Que vão desde a desapropriação de bens particulares até a alienação de bens públicos. Uma das formas de atuação conjugada do Estado com o particular é o contrato administrativo, derivado de um procedimento licitatório.

Há situações em Que a Administração recebe da lei autorização para deixar de licitar, se assim entender conveniente ao interesse do serviço; hipóteses há em Que a Administraçâa defronta-se com inviabilidade fática para licitar, por expressa vedação da lei. As hipóteses de dispensabilidade do art. 24, da Lei n. ${ }^{\circ} 8.666$, de 21 de junho de 1993, constituem rol taxativo e a dispensa de licitação em razão da emergência - caracteriza-se pela urgência de atendimento de situação Que possa ocasionar prejuízo ou comprometer a segurança de pessoas, obras, serviços ou equipamentos.

Na prática, a situação de emergência muitas vezes decorre da falta de planejamento administrativo e isto tem sido constantemente detectado pelos órgãos de controle, tanto interno como externo. Não obstante, o atendimento de certas situações pelo poder público há de ser imediato, sob pena de a procrastinação causar prejuízos ao interesse público, sendo a dispensa de licitação prevista no inciso $\mathrm{V}$, do art. 24 , alternativa transitável para o gestor público, observadas as vinculações jurídicas aplicáveis à espécie.

A rigor, em Que pese argumentos de autoridade em contrário, a licitação não é um princípio, mas tão-somente um instituto, cuja natureza é de procedimento administrativo. Lembra Celso Antônio Bandeira de Mello' oue a licitação tem dupla função, conforme dito na

\footnotetext{
' DE MELLO, Celso Antônio Bandeira, Curso de Direito Administrativo, 2002, p. 468.
} 
própria lei de licitações: garantir o princípio constitucional da isonomia e selecionar a proposta mais vantajosa para a administração. Enganam-se aqueles que vêem na licitação o garante (somente) do princípio da isonomia, porquanto pensar assim seria o mesmo que dizer que nas dispensas de licitação tal caractere está dispensado. Não é verdade. Primeiro que a licitação, como conjunto de procedimentos formais, não tem conseguido seu intento de soldado da moralidade pública. De outra, o art. 26 da Lei n ${ }^{\circ} 8.666 / 93$, ao estabelecer a necessidade de justificação do preço e a motivação da escolha da empresa a ser contratada para a execução do objeto da dispensa, em realidade Quer garantir o núcleo duro dos princípios da moralidade, da isonomia e da igualdade.

\section{PRINCÍPIOS QUE NORTEIAM O PROCEDIMENTO LICITATÓRIO}

Licitação, de acordo com a lição de Cretella lúnior ${ }^{2}$, tem o sentido preciso e técnico de procedimento administrativo preliminar complexo, a que recorre a Administração Pública Quando, desejando celebrar contrato com o particular, referente a compras, vendas, obras, trabalhos ou serviços, seleciona, entre várias propostas, a que melhor atende ao interesse público, baseandose para tanto em critério objetivo, fixado de antemão, em edital, a que se deu ampla publicidade.

Estabelece o inciso XXI do art. 37 da Constituição Federal:

[...]ressalvados os casos especificados na legislação, as obras, serviços, compras e alienações serão contratados mediante processo de licitação pública Que assegure igualdade de condições a todos os concorrentes, com cláusulas que estabeleçam obrigações de pagamento, mantidas as condiçóes efetivas da proposta, nos termos da leí, o Qual somente permitirá as exigências de Qualificação técnica e econômica indispensáveis à garantia do cumprimento das obrigações.

É de se ressaltar que antes da Reforma Administrativa de 1967 o termo empregado para licitação era concorrência pública. Na Lei n. ${ }^{\circ} 4.401 / 64$. promulgada três anos antes do Decreto-lei n. ${ }^{\circ}$ 200/67, surgiu, pela primeira vez, o vocábulo licitação como sinônimo de concorrência.

De outro lado, o Decreto-lei n. ${ }^{\circ}$ 200/67 apenas se referia à Administração Direta e às autarquias, enquanto que o Estatuto das Licitações em vigor, Lei n. ${ }^{\circ} 8.666$, de 21 de junho de 1993, contempla também as fundações públicas, empresas públicas, sociedades de economia mista e demais entidades controladas direta ou indiretamente pela União, Estados, Distrito Federal e Municípios. Todavia, a Emenda Constitucional n. ${ }^{\circ}$ 19, de 04.06.98, modificou novamente o quadro das entidades abrangidas pela Lei n. ${ }^{\circ} 8.666 / 93$. Quando estabeleceu que

${ }^{2}$ CRETELLA júnior, losé. Das Licitaçōes Públicas, Forense, 1995, p. 13. 
lei própria estabelecerá o estatuto jurídico da empresa pública, da sociedade de economia mista e de suas subsidiárias Que explorem atividade econômica de produção ou comercialização de bens ou de prestação de serviços e disporá sobre licitação e contratação.

$\mathrm{O}$ art. 3.\% , da Lei de Licitações informa os princípios norteadores da licitação: da legalidade, da impessoalidade, da moralidade, da igualdade, da publicidade, da probidade administrativa, da vinculação ao instrumento convocatório, do julgamento obj̣ctivo e dos Que lhes são correlatos.

Explicitação concreta do princípio da legalidade encontra-se no art. $4 .{ }^{\circ}$ da lei, segundo o Qual todos Quantos participem de licitação promovida pelos órgãos ou entidades a Que se refere o art. $1 .^{\circ}$ têm direito público subjetivo à fiel observância do pertinente procedimento estabelecido nesta Lei., podendo Qual@uer cidadão acompanhar o seu desenvolvimento, desde Que não interfira de modo a perturbar ou impedir a realização dos trabahthos.

O princípio da impessoalidade encarece a proscrição de Quaisquer favoritismos ou discriminaçōes impertinentes, sublinhando o dever de que, no procedimento licitatório, sejam todos os licitantes tratados com absoluta neutralidade. Tal princípio não é senão uma forma de designar o princípio da igualdade de todos perante a Administração.

O princípio da igualdade implica o dever não apenas de tratar isonomicamente todos os Que afluírem ao certame, mas também o de ensejar oportunidade de disputá-lo a Quaisquer interessados que, desejando dele participar, podem oferecer as indispensáveis condiçóes de garantia. $\mathrm{O} \S 1 .^{\circ}$ do art. $3 .^{\circ}$ da Lei n. ${ }^{\circ} 8.666 / 93$ próbe Que o ato convocatório do certame admita, preveja, inclua ou tolere cláusulas ou condiçóes capazes de frustrar ou restringir o caráter competitivo do procedimento licitatório e veda o estabelecimento de preferências ou distinções em razão da naturalidade, sede ou domiclio dos licitantes, bem como entre empresas brasileiras ou estrangeiras, ou de QualQuer outra circunstância impertinente ou irrelevante para objeto do contrato.

O princípio da publicidade impóe que os atos e termos da licitação - no Que se inclui a motivação das decisōes - sejam efetivamente expostos ao conhecimento de Quaisquer interessados. É um dever de transparência, em prol não apenas dos disputantes, mas de QualQuer cidadão. A Lei n. ${ }^{\circ} 8.666$, no $\S 3 .^{\circ}$ do art. $3 .^{\circ}$, estatui Que a licitação não será sigilosa, sendo públicos e acessíveis ao público os atos de seu procedimento, salvo Quanto ao conteúdo das propostas até a respectiva abertura. Acresce que o art. $4 .^{\circ}$ também menciona o direito de Quałeuer cidadão acompanhar o desenvolvimento do certame. Demais disso, existem outros preceptivos que facultam uma fiscalização do certame por qualouer pessoa, como os artigos 15 , $\S \S 2 .^{\circ}$ e $6 .^{\circ}, 16,41, \S 1 .^{\circ}$ e $113, \S 1 .^{\circ}$, todos insertos na Lei de Licitaçöes.

O princípio da moralidade significa Que o procedimento licitatório terá de se desenrolar na conformidade de padrōes éticos prezáveis, o Que impõe, para a Administração e licitantes, um comportamento escorreito, liso e honesto.

Especificamente para a Administração Pública, tal princípio está reiterado na referência ao princípio da probidade administrativa. Sublinha-se aí que o certame haverá de ser por ela 
conduzido em estrita obediência à pauta da moralidade, no que se inclui, evidenternente, não só a correção defensiva dos interesses de Quem a promove, mas, também, às exigências de lealdade e boa-fé no trato com os licitantes.

O princípio da vinculação ao instrumento convocatório obriga a Administração a respeitar estritamente as regras Que haja previamente estabelecido para disciplinar o certame, consignado no art. 41 da Lei n. ${ }^{\circ} 8.666$.

O princípio do julgamento objetivo almeja, como é evidente, impedir que a licitação seja decidida sobo influxo do subjetivismo, de sentimentos, impressões ou propósitos pessoais dos membros da comissão julgadora, preocupação enfatizada no art. 45 da Lei n. ${ }^{\circ}$ 8.666/93. Cumpre reconhecer Que objetividade absoluta só se pode garantir previamente nos certames decididos unicamente pelo preço. Quando entra em causa Qualidade, técnica e rendimento muitas vezes indispensáveis para a aferição das propostas - nem sempre será possivel atingirse o ideal da objetividade extrema, pois, Quando os bens ou serviços são fortemente aparentados nestes atributos, a primazia de um ou de outro depende de apreciações irredutíveis a um plano excludente de opiniões pessoais.

Note-se Que a ampla participação no certame pressupõe publicidade e Que não pode haver igualdade sem o estrito cumprimento do edital.

\section{CONTRATAÇÃo DIRETA}

A realização de QualQuer licitação depende da ocorrência de certos pressupostos. À falta deles, o certame licitatório seria um autêntico sem-sentido ou simplesmente não atenderia às finalidades em vista das Quais foi concebido. Ditos pressupostos são de três ordens, a saber: a) pressuposto lógico; b) pressuposto jurídico; e c) pressuposto fático.

É pressuposto lógico da licitação a existência de uma pluralidade de objetos e de uma pluralidade de ofertantes. Sem isto não há como conceber uma licitação. Dita impossibilidade é reconhecível já no próprio plano de um simples raciocínio abstrato.

É pressuposto jurídico o de que, em face do caso concreto, a licitação possa se constituir em meio apto, ao menos em tese, para a Administração acudir ao interesse Que deve prover.

É pressuposto fático da licitação a existência de interessados em disputá-la.

Posto Que a função do instituto da licitação é servir o interesse público, em casos Que tais percebe-se que falece o pressuposto jurídico para sua instauração. Com efeito: a licitação não é um fim em si mesmo; é um meio para chegar utilmente a um dado resultado: o travamento de uma certa relação jurídica. Quando nem mesmo em tese pode cumprir tal função, seria descabido realizá-la. Embora fosse logicamente possível realizá-la, seria ilógico fazê-lo em face do interesse jurídico a Que se tem que atender. 
A Constituição Federal acolheu a presunção de Que prévia licitação produz a melhor contratação - entendida como aQuela Que assegura a maior vantagem possível à Administração Pública. Mas a própria Constituição se encarregou de limitar tal presunção absoluta, facultando a contratação direta nos casos previstos em lei.

A supremacia do interesse público fundamenta a exigência, como regra geral, de licitação prévia para contrataçỗes da Administração Pública. Existem hipóteses em Que a licitaçáo formal seria impossível ou frustraria a própria consecução dos interesses públicos. O procedimento licitatório normal conduziria ao sacrificio do interesse público e não asseguraria a contratação mais vantajosa.

Não é absurda a afirmação de que a contratação direta é uma modalidade extremamente anômala de licitação. O próprio legislador determinou as hipóteses em Que se aplicam os procedimentos licitatórios simplificados. Por igual, definiu os casos de não-incidência do regime formal de licitação.

Diante de situaçôes desta ordem é Que se configuram os casos acoihidos na legislação como de dispensa de certame licitatório ou os Que terão de ser considerados como de inexigibilidade dele.

Certamente em atenção à diversidade de hipóteses em Que é cabível a adjudicação direta, isto é, a eleição da contraparte independentemente de licitação, a Lei n. ${ }^{\circ} 8.666 / 93$ tanto prevê casos de dispensa de licitação Quanto de sua inexigibilidade.

Em tese, a dispensa contempla hipóteses em Que a licitação seria possível; entretanto razões de tomo justificam oue se deixe de efetuá-la em nome de outros interesses públicos Que merecem acolhidas.

Os casos Qualificados pela lei como de licitação dispensável estão arrolados nos incisos I a XXIV do art. 24 da Lei de Licitaçōes. A este total haver-se-ão de aditar as hipóteses, previstas no art. 17, em Que a Lei declara dispensada a licitação.

De par com as figuras de licitação dispensável e dispensada, Celso Antônio Bandeira de Mello ${ }^{3}$ reconhece a existência de licitação proibida. Informa Que o exemplo típico, mas não único, é aquele que ao tempo do Decreto-lei 2.300, de 2 I de novembro de 1986, estava formalmente identilicado como tal e hoje se encontra referido no art. 24, IX, entre as hipóteses de licitação dispensável; a saber: Quando houver possibilidade de comprometimento da segurança nacional, nos casos estabelecidos em decreto do Presidente da República, ouvido o Conselho de Defesa Nacional.

${ }^{3}$ DE MELLO, Celso Antônio Bandeira. Curso de Direito Administrativo, São Paulo, 2002, p. 492. 


\subsection{Contratação Emergencial}

$\mathrm{O}$ inciso IV do art. 24 da Lei $n .{ }^{\circ} 8.666 / 93$, estabelece:

Art. 24. É dispensável a licitação:

IV - nos casos de emergência ou de calamidade pública, Quando caracterizada urgência de atendimento de situação Que possa ocasionar prejúzo ou comprometer a segurança de pessoas, obras, serviços, equipamentos e outros bens, públicos ou particulares, e somente para os bens necessários ao atendimento da situação emergencial ou calamitosa e para as parcelas de obras e serviços Que possam ser concluídas no prazo máximo de 180 (cento e oitenta) dias consecutivos e ininterruptos, contados da ocorrência da emergência ou calamidade, vedada a prorrogação dos respectivos contratos;

O administrador, para deliberar pela não-realização de licitação, deve ter redobrada cautela. No caso específico das contrataçóes diretas, emergência significa necessidade de atendimento imediato a certos interesses. Demora em realizar a prestação produziria risco de sacrifício de valores tutelados pelo ordenamento jurídico. Como a licitação pressupõe certa demora para seu trâmite, submeter a contratação ao processo licitatório propiciaria a concretização do sacrifício a esses valores. A simples descontinuidade na prestação dos serviços não justifica, em tese, a realização de contrato emergencial. Compõem a situação de emergência certa dose de imprevisibilidade da situação e a existência de risco em potencial a pessoas ou coisas, que requerem urgência de atendimento.

Não é possivel ao administrador público pretender utilizar uma situação de emergência ou calamitosa para dispensar a licitação em aquisiçōes que transcendam o objeto do contrato, Que em casos emergenciais deve ser feito tão-somente no limite do indispensável ao afastamento do risco. Haverá, assim, profunda correlaçāo entre o objeto pretendido pela Administração e o interesse público a ser atendido. A correlação entre o objeto do futuro contrato e o risco, limitado, cuja ocorrência se pretenda evitar, deve ser íntima, sob pena de incidir o administrador em líicita dispensa de licitação.

Nesse sentido, adverte |.C. Mariense Escobar ${ }^{4}$ Que a situação emergencial ensejadora da dispensa é aquela que resulta do imprevisível, e não da inércia administrativa. A situação adversa, dada como emergência ou de calamidade pública, não pode ter se originado, total ou parciaimente, da falta de planejamento, da desidia administrativa ou da má gestão dos recursos disponíveis, ou seja, não pode, em alguma medida, ser atribuída à culpa ou dolo do agente público que tinha o dever de agir para prevenir a ocorrência de tal situação.

A hipótese merece interpretação cautelosa, segundo Marçal Justen Filho ${ }^{5}$. A contratação administrativa pressupõe atendimento ao interesse público. Isso significa Que a ausência da

\footnotetext{
${ }^{4}$ ESCOBAR, 1.C. Mariense. Licitaçăo, Teoria e Prática, Livraria do Advogado, 1993, p. 72.

${ }^{5}$ JUSTEN Fitho, Marçal. Comentários à Lei de Licitaçöes e Contratos Administrativos, Dialética, 2002, p. 239.
} 
contratação representaria um prejúzo para o bem público. Na generalidade dos casos em Que o Estado dispóe-se a contratar, é motivado a atuar para evitar dano potencial. Toda e qualquer contratação administrativa retrata a necessidade e a conveniência de uma atuação conjugada entre o Estado e terceiros. Uma interpretação ampla do inciso IV acarretaria, por isso, a dispensa de licitação como regra geral. O argumento da urgência sempre poderia ser utillzado.

A dispensa de licitação e a contratação imediata representam uma modalidade de atividade acautelatória do interesse público.

O mesmo autor ${ }^{6}$ ensina Que para a dispensa de licitação com fulcro no art. 24 , inciso IV, incumbe à Administração Pública avaliar a presença de dois requisitos: o primeiro deles é a demonstração concreta e efetiva da potencialidade de dano: deve ser evidenciada a urgência da situação concreta e efetiva, não se tratando de urgência simplesmente teórica. A expressão prejúzo deve ser interpretada com cautela, por comportar significações muito amplas. Não é Qualeuer prejuízo que autoriza dispensa de licitação, o mesmo deverá ser irreparável. Cabe comprovar se a contratação imediata evitará prejuízos Que não possam ser recompostos posteriormente. O comprometimento à segurança significa o risco de destruição ou de seQüelas à integridade física ou mental de pessoas ou, Quanto a bens, o risco de seu perecimento ou deterioração. $O$ segundo requisito é a demonstração de que a contratação é via adequada e efetiva para eliminar o risco: a contratação imediata apenas será admissível se evidenciado Que será instrumento adeQuado e eficiente de eliminar o risco. Se o risco de dano não for suprimido através da contratação, inexiste cabimento da dispensa de licitação.

Trata-se de expor a relação da causalidade entre a ausência de contratação e a ocorrência de dano - ou, mais precisamente, a relação de causalidade entre a contrataçáo e a supressão do risco de dano. Em última análise, aplica-se o princípio da proporcionalidade. A contratação deverá ser o instrumento satisfatório de eliminação do risco de sacrifício dos interesses envolvidos. Mas não haverá cabimento em promover contratações que ultrapassem a dimensão e os limites da preservação e realização dos valores em risco.

o Tribunal de Contas da União firmou entendimento, por meio da decisão pienária $347 / 1994^{\top}$, no sentido de Que são pressupostos da aplicação do caso de dispensa de licitação preconizado no art. 24 , inciso $\mathrm{N}$, da Lei n. ${ }^{\circ} 8.666 / 93$, primeiramente, que a situação adversa, dada como de emergência ou de calamidade pública, não se tenha originado, total ou parcialmente, da falta de planejamento, da desídia administrativa ou da má gestão dos recursos disponíveis, ou seja, Que ela não possa, em alguma medida, ser atribuída à culpa ou dolo do agente público Que tinha o dever de agir para prevenir a ocorrência de tal situação. Em segundo, Que exista urgência concreta e efetiva do atendimento à situação decorrente do estado emergencial ou calamitoso, visando afastar risco de danos a bens ou à saúde ou à vida de

- IUSTEN Filho, Marçal. Comentários à Lei de Licitaçóes e Contratos Administrativos, Diatética, 2002, p. 239 e 240.

${ }^{7}$ BRASIL.Tribunal de Contas da União. Processo 009.248/1994-3, 1994. 
pessoas. Terceiro, Que o risco, alérn de concreto e efetivamente provável, se mosire iminente e especialmente gravoso e Quarto Que a imediata efetivaçāo, por meio de contratação corn terceiro, de determinadas obras, serviços ou compras, segundo as especificações e Quantitativos tecnicamente apurados, seja o meio adequado, efetivo e eficiente de afastar o risco iminente detectado.

\subsection{Desídia Administrativa e o Princípio da Eficiência}

Na acepção trazida pelos dicionários da língua portuguesa, desídia tem o mesmo sentido eue inércia, negligência, desleixo, descaso ou incúria. No direito público desídia administrativa é sinônimo de falta de planejamento ou de ausência de previsão para necessidades perfeitamente previsiveis.

O planejamento contempla a seleção de alternativas de solução dos problemas com sua análise de custo-beneficio e o estabelecimento de indicadores qualitativos e Quantitativos, propiciando uma visão global da atividade administrativa antes da sua implementação e com muita utilidade nas etapas de acompanhamento e avaliação linal, capaz de reduzir riscos e incertezas, direcionar recursos adeQuados e propiciar condições para obtenção de resultados positivos e eficazes para o interesse público.

Traduz-se no princípio da eficiência, faceta de um princíplo mais amplo tratado de há muito no Díreito Italiano: o princípio da boa administração.

Sem dúvida, o princípio da eficiência veio a lume para viabilizar a reforma do Estado, sendo implementado no nível infraconstitucional por instrumentos de otimização ou de privatização, em sentido amplo, das atividades estatais (Leis Federais 8.987/95, 9.074/95, 9.491/97, 9.637/98, 9.649/98, 9.790/99). Porém, este é apenas um dos efeitos da consagração legislativa do princípio da eficiência. O outro indica uma revalorização do conteúdo da atuação administrativa, inclusive a decorrente da competência discricionária, cujo parâmetro será também a eficiência.

Adotado expressamente no art. 37, caput, da Constituição Federal, dá uma nova dimensão à Administração Pública, aproximando-a mais do dever de boa administração. Os administrados são titulares de dois direitos subjetivos genéricos e fundamentais em face da Administração Pública: legalidade e funcionamento. O primeiro impõe garantias ao administrado pela instituição de limites à atuação da Administração Pública, sujeita a um dever negativo de abstenção. O segundo conjugado ao primeiro expressa a obrigação da Administração Pública oferecer certas prestações positivas aos administrados, sobretudo, Quando a constituição ou as leis ordenam. genérica ou especificamente, Innhas de conduta administrativa para satisfação de interesses dos administrados, as Quais ela não pode renunciar em função da primazia do interesse público e sua indisponibilidade. 
O Acórdão 272/2002 $2^{8}$ Segunda Câmara - Tribunal de Contas da União, traz o exemplo mais comum de contratação direta na forma do art. $24, \mathrm{~N}$, em Que a situação dada como de emergência se origina, total ou parcialmente da falta de planejamento, ou da desídia administrativa:

Desde a assinatura dos contratos de prestação dos serviços já se sabia Que, após o decurso do prazo de vigência do ajuste ( 2 meses, prorrogável uma vez), haveria a necessidade de realizar-se novo procedimento licitatório.

Teve, por conseguinte, o gestor lapso de tempo mais do que suficiente para organizar e providenciar as medidas administrativas cabíveis de forma a evitar a situação de urgência Que efetivamente ocorreu ao final da vigência dos ajustes respectivos.

\subsection{Culpa do Administrador e Dever de Contratar}

A base jurídico-constitucional da conduta do Administrador exibe um argumento de especial relevância. Criada a situação de necessidade de contratação, o administrador público foi colocado diante de situação cujas opções de solução são claras: a contratação emergencial.

Sendo princípios constitucionais expressos à administração, cuja extensão à administração indireta a Constituição faz induvidosa, a legalidade e a eficiência, é nessa faixa jurídica Que se há de encontrar a base validadora da conduta, para oferecer à lei de licitaçóes a melhor leitura diante do Quadro fático composto. Ressalta-se Que essa conclusão não exime, das sançóes cabíveis, o responsável que deu causa à situação emergencial surgida. Assunto de natureza similar foi abordado pelo Ministério Público junto ao Tribunal de Contas da União, acatado pelo Plenário ao prolatar o Acórdão $46 / 2002^{\circ}$, aduzindo Que as balizas legais, no atinente ao conceito de emergência, devem ser de tal ordem Que impliquem urgência de atendimento da situação, sob pena de se ocasionarem prejuízos ou se comprometer a segurança de pessoas, obras, serviços, bens ou equipamentos.

Como ensina Gilmar Ferreira Mendes acerca do princípio da proporcionalidade, o meio não será necessário se o objetivo almejado puder ser alcançado com a adoção de medida que se revele a um só tempo adequada e menos onerosa. Na prática, adequação e necessidade não têm o mesmo peso ou relevância no júzo de ponderação. Assim, apenas o que é adequado pode ser necessário, mas o que é necessário não pode ser inadequado, pelo que um juízo definitivo sobre a proporcionalidade da medida há de resultar da rigorosa ponderação e do possivel equilíbrio entre o significado da intervenção para o atingido e os objetivos perseguidos pelo legislador (proporcionalidade em sentido estrito).

8 BRASIL.Tribunal de Contas da Uniăo. Processo 006.932/1995-9, 2002.

${ }^{9}$ BRASIL.Tribunal de Contas da União. Processo 006.932/1995-9, 2002. 
Determinar Que não se dispense licitação Quando a culpa for da Administração é dupla lesão, porQuanto permanece a falta de planejamento e aparece a descontinuidade da prestação de um serviço público ou abandono de direitos sociais. A não realização de licitação é ofensa a dispositivo, entretanto este tem flexibilidade constitucional.

Adentrando na análise do caso, trago à colação o ensinamento de Paulo Bonavides ${ }^{10}$. Que dá o primeiro elemento do princípio da proporcionalidade: o da pertinência, traduzido como princípio da adequação por Gilmar Ferreira Mendes. Para ele, sua aplicação deve responder se uma medida é o meio certo para levar a cabo um fim baseado no interesse público. Examinase aí a adeQuação, a conformidade ou a validade do fim. Seguindo as pegadas do doutrinador e adentrando na proporcionalidade stricto sensu, só se age desta forma Quando a escolha recai sobre o meio ou os meios Que, no caso espećfico, levarem mais em conta o conjunto de interesses em jogo.

A norma não traz Qualuuer menção à causa Que originou a situação de emergência, bastando-the a referida situação e a possibilidade que dela derive a ocorrência de prejuízo a pessoas e bens públicos ou da coletividade. Assim, dizer que a lícitação não pode ser afastada Quando a situação é criada por culpa do administrador é desbordar o alcance da norma e punir o destinatário da norma.

O Que autoriza o dever de dispensar a licitação é a situação emergencial, não a causa de sua ocorrência. A teoria da imprevisão seria utilizada para averiguação da licitude do proceder administrativo. A falta de planejamento estaria aperfeiçoada com a constatação de uma situação de emergência, não com a adoção da contratação direta por dispensa. Não se pode confundir hipótese normativa criada para um caso dado com elemento de conduta objetiva utilizável para averiguar descumprimento de norma legal.

Se estiverem presentes todos os requisitos previstos no dispositivo, cabe dispensa de licitação, independente de culpa do servidor pela não realização do procedimento na época oportuna. A inércia do servidor, dolosa ou culposa, não pode vir em prejuizo do interesse público maior a ser tutelado pela Administração.

No caso de emergência ficta ou fabricada, há negligência, não urgência. Apesar disso, contrata-se, e pela negligência responderá a autoridade omissa, depois de devidamente apurados todos os fatos.

A emergência é um conceito relacional entre uma situação fática anormal e a realização de certos valores. Tais valores seriam os fins a serem atingidos pelo Direito Público. Assim, a situação de risco colocania em risco esses mesmos valores. Ainda segundo o autor, a contratação emergencial teria o caráter cautelar, pornuanto a intempestividade redundaria em inefetividade do gasto.

A situação de emergência criada pela desídia do administrador terá a capacidade de gerar afronta aos artigos $15, \S 7^{\circ}$, inciso II (Que patenteia o princípio do planejamento), da Lei

\footnotetext{
${ }^{10}$ BONAVIDES, Paulo. Curso de Direito Constitucional, Matheiros, 2004, p. 396.
} 
$\pi^{\circ} 8.666 / 93$ e o art. 74 , incisos I (dever de atendimento das metas dos programas de governo) ell (obrigação de ser eficaz), da Constituição Federal. Este é o dispositivo descumprido Quando da desídia na prevenção da situação emergencial. Estando a situação emergencial formada, estará automaticamente subsumida ao caso a hipótese do art. 24, inciso IV, da Lei n ${ }^{\circ} 8.666 / 93$.

\subsection{Desídia Administrativa e Responsabilidade do Servidor}

Distingue-se a emergência real, resultante do imprevisível, daquela resultante da incúria ou inércia administrativa. A ambas há idêntico tratamento, no que atina à possibilidade de contratação direta. Constatada a situação a reQuerer urgente contratação, não poderia a entidade ter sido tolhida no cumprimento de sua missão institucional, ao ser prejudicada pela Falta do serviço que the era imediatamente indispensável, porém não exime o responsável pela falha administrativa de sofrer as sanções disciplinares compativeis.

A despeito disso, o Tribunal de Contas da União, através do Acórdão 1490/2003" Segunda Câmara, entende Que, ainda Que por inércia da administração resultou caracterizada a situação emergencial, fato Que ampara a contratação direta, não exime o agente que deu causa à situação de urgência de ser responsabilizado, mas não aqueles Que endossaram a contratação direta diante da urgência ocasionada.

Marçal Justen Filho ${ }^{12}$ ensina Que isso não significa defender o sacrifício do interesse público como conseqüência da desídia do administrador. Havendo risco de lesão ao interesse público, a contratação deve ser realizada, punindo-se o agente Que não adotou as cautelas necessárias. O que é necessário é verificar se a urgência existe efetivamente e, ademais, a contratação é a melhor possível nas circunstâncias. Comprovando-se que, mediante licitação formal e comum, a Administração obteria melhor resultado, o prejuízo sofrido deverá ser indenizado pelo agente que omitiu as providências necessárias.

Semethante posicionamentó é defendido por Maria Sylvia Zanella Di Pietro ${ }^{i 3}$ aduzindo Que se estiverem presentes todos os requisitos previstos no dispositivo cabe a dispensa de licitaçâa, independentemente da culpa do servidor pela não realização do procedimento na época oportuna. Se a demora do procedimento puder ocasionar prejuízo ou comprometer a segurança de pessoas, obras, serviços, eQuipamentos e outros bens, públicos ou particulares, a dispensa tem que ser feita, porque o interesse público em jogo - a segurança - leva necessariamente a essa conclusão.

11 BRASIL.Tribunal de Contas da União. Processo 016.304/1995.0, 2003.

12 JUSTEN Filho, Marçal. Comentários à Lei de Licitações e Contratos Administrativos, Dialética, 2002, p. 152 a 154.

3 DI PIETRO, Maria Sylvia Zanella. Temas Polêmicos sobre Licitaçốes e Contratos, Malheiros, 1994, p. 80. 


\subsection{Descentralização Financeira no Final do Exercício}

Tema bastante polêmico diz respeito à contratação direta com base no art. 24, inciso IV, em face da descentralização de recursos financeiros ao final do exercício e a impossibilidade de conclusão do procedimento licitatório em tempo hábil.

O princípio da anualidade do orçamento público é dos mais antigos do direito financeiro. Na Constituição Federal de 1988 encontra-se, implicitamente, nos artigos 48, II. 165 , Ill e $\$ 5 . \circ$, e 166 , todos se referindo a orçamentos anuais.

A Lei n. ${ }^{0} 4.320$, de 17 de março de 1964 , Que estatui normas gerais de direito financeiro, estabelece Que imediatamente após a promulgação da Lei de Orçamento e com base nos limites nela fixados, o Poder Executivo aprovará um Quadro de cotas trimestrais da despesa Que cada unidade orçamentária fica autorizada a utilizar. A fixação das cotas objetivará assegurar às unidades orçamentárias, em tempo útil, a soma de recursos necessários e suficientes a melhor execução do seu programa anual de trabalho, como preceitua o art. 48 da lei.

A existência de recursos financeiros para o cumprimento das obrigações é condição para a realização da licitação e, também, para a contratação direta.

O art. $7 . .^{\circ}, \S 2 .^{\circ}$, inciso III e o art. 14 , ambos da Lei n. ${ }^{\circ} 8.666 / 93$, o art. 60 da Lei $n .{ }^{\circ}$ 4.320/64 e o art. I6, inciso II da Lei Complementar n. ${ }^{\circ} 10$ / $/ 2000$, respectivamente, estabelecem: Art. 7.9

$\S 20$ As obras e os serviços somente poderão ser licitados Quando: III - houver previsão de recursos orçamentários que assegurem o pagamento das obrigações decorrentes de obras ou serviços a serem executadas no exercício financeiro em curso, de acordo com o respectivo cronograma;

Art. 14. Nenhuma compra será feita sem a adequada caracterização de seu objeto e indicação dos recursos orçamentários para seu pagamento, sob pena de nulidade do ato e responsabilidade de quem the tiver dado causa. Art. 60. É vedada a realização de despesa sem prévio empenho.

Art. 16. A criação, expansão ou aperfeiçoamento de ação governamental Que acarrete aumento da despesa será acompanhado de:

II - declaração do ordenador da despesa de Que o aumento tem adequação orçamentária e financeira com a lei orçamentária anual e compatibilidade com o plano plurianual e com a lei de diretrizes orçamentárias.

É prática corrente na Administração Pública, ou seja, dá-se a descentralização ou repasse de recursos às unidades gestoras, para atender as despesas com contratação de bens, obras e serviços fixadas em proposta orçamentária do exercício anterior, ao final do exercício financeiro seguinte.

Por vezes os valores descentralizados no final do exercício autorizam a utilização de uma determinada modalidade licitatória, como a concorrência e a tomada de preços, tornando inexeuüivel sua realização em face do cumprimento dos prazos legais estipulados na Lei de Licitações como os previstos no $\S 2 .^{\circ}$ do art. 21 . 
O princípio capital para a configuração do regime jurídico-administrativo é o da legalidade. Outros merecem igualmente consagração no direito público, conQuanto não mencionados na Constituição Federal por serem implicações evidentes do próprio Estado de Direito e. pois, do sistema constitucional como um todo, como o é o princípio da proporcionalidade.

À luz deste princípio, as competências administrativas só podem ser validamente exercidas na extensão e intensidade proporcionais ao que seja realmente demandado para o cumprimento da finalidade de interesse público a que estão atreladas.

O conteúdo substancial da lei não predica a mera coincidência da conduta administrativa com a letra da lei, mas reclama adesão ao espírito dela, à finalidade Que a anima.

O dispositivo Que autoriza a contratação direta em virtude de emergência não traz um rol taxativo de suas ocorrências, nem poderia fazê-lo de maneira enunciativa. A cláusula geral se fez necessária ante a infinidade de hipóteses existentes e sua aplicação ao caso concreto.

Busca-se a legitimidade da contratação com fulcro no inciso IV, nestes casos em Que ocorrer a descentralização de recursos somente no final do exercício financeiro, conjugando-se uma dose de interesse público a ser tutelado pela Administração Pública com a necessidade do objeto a ser contratado, restringindo-se ao necessário para o cumprimento da finalidade de interesse público.

De nada adiantaria pensar-se na finalidade cogitada pelo legislador se esta finalidade não tivesse condições de ser aperfeiçoada Quando de sua aplicação. Direito existe na e para a sociedade. Logo, o resultado Que ele por aí produza concretamente, comprovará a sua justeza e a sua justiça, adotados critérios de proporcionalidade.

O administrador público não cria a necessidade de determinado bem, obra ou serviço em face da disponibilidade financeira existente em determinado momento. A fixação das despesas ocorre no exercício financeiro anterior e, no exercício seguinte, tem-se uma expectativa de crédito para atendê-las. leciona:

I. I. Gomes Canotilho ${ }^{14}$, ao tratar do princípio da justeza ou da conformidade funcional,

O princípio da conformidade constitucional tem em vista impedir, em sede de concretização da constituição, a alteração da repartição de funções constitucionalmente estabelecida. O seu alcance primeiro é este: o órgão (ou órgãos) encarregado da interpretação da lei constitucional não pode chegar a um resultado que subverta ou perturbe o esquema organizatóriofuncional constitucionalmente estabelecido (Ehmke). É um princípio importante a observar pelo Tribunal Constitucional, nas suas relaçôes com o legislador e governo, e pelos órgãos constitucionais nas relaçôes verticais do

${ }^{14}$ CANOT!LHO, I.1. Gomes. Direito Constitucional e Teoria da Constituição, p. 1224. 
poder (Estado/tegiōes, Estado/autarquias locais). Este princípio tende, porém, hoje, a ser considerado mais como um princípio autônomo de competência do Que como um princípio de interpretação da constituição.

Significa dizer concretamente Que, independentemente do método de interpretação Que se utilize, ele deve ser obrigatoriamente considerado Quando o tema envolvido é uso de competência por órgão/pessoa estatal que eventualmente possa se refletir no âmbito de outros órgãos ou entídades estatais.

A execução do programa anual de trabałho do órgão público, em tempo útil, disposto no art. 48 da Lei n. ${ }^{\circ} 4.320$, de 17 de março de 1964, não afasta a incidência da regra contida no inciso IV, do art. 24 , da Lei $.^{\circ} 8.666 / 93$, traduzido no princípio da confiança recíproca entre os órgãos:

a) Las normas constitucionales que señalan funciones o que dotan a los órganos de competencias tienen Que ser interpretadas tomando en consideración el efecto generador de unidad (integración) de la constitución. En consecuencia, el Tribunal Constitucional Federal no ha considerado las relaciones entre la Federación y los Länder como relaciones de separación, sino - sostenidas por el principio de confianza federal - - como relaciones de recíproca sintonización, coodinación, información, repeto y participación conjunta.

Lo Que se considera Que tiene Que tener vigencia como algo seguro en la relación Federecaión/Länder por la jurisprudencia del Tribunal Consitucional Federal, tiene Que tener vigencia también para el comportamiento recíproco de los órganos del estado. En este sentido hay que dar por supuesto el principio fundamental de la confianza recíproca entre los órganos. Los órganos del estado tienen Que comportarse entre sí de tal manera Que puedan ejercitar sus competencias constitucionales de manera responsable y concienzuda, libres de presiones y de urgencias. Efectos sorpresa, golpes de mano, entre otras cosas, no son sólo en consecuencia contrarios al estilo con que se debe proceder, sino también anticonstitucionales. ${ }^{15}$

A aplicação desse princípio, traduzido na necessidade de os órgãos públicos conduzirem, planificarem e conformarem suas atuaçôes com a proteção da confiança mútua, não vem só, antes exigindo a demonstração do interesse público a ser tutelado pela Administração, a necessidade do objeto a ser contratado e a demonstração de Que a ausência de contratação poderá provocar a paralisação ou prejudicar a regularidade de suas atividades específicas.

As leis administrativas, Quaisquer Que sejam, podem ser interpretadas extensivamente sempre Que o rigor das regras técnicas o permita. Essas limitaçôes podem ampliar-se Quando o fim da lei, o sistema legislativo, o regime político, a própria história demonstrarem a necessidade

is STERN, Klaus. DERECHO DEl. ESTADO DE LA REPUBLICA FEDERAL ALEMANHA, 1997, p. 296. 
de assim se entender. Tudo é questão de honestidade de processos e de intenções. Porque o perigo da interpretação extensiva em tais matérias reside na abusiva invocação Que dela façam autoridades menos escrupulosas a fim de legitimar prepotências. Esse emprego desonesto não pode, porém, excluir o uso legítimo.

Na esfera federal é conhecido o esforço Que o Tribunal de Contas da União desenvolveu para concretizar o comando legal, na sua meihor expressão. Entre os inúmeros esforços um tornou-se memorável, consolidado na Decisão n. ${ }^{0}$ 524/99 - Plienário, citado por lorge Ulisses Jacobi Fernandes:

A Universidade Federal do Rio Grande do Sul recebeu recursos para a aquisição de computadores, mas com tempo de tal modo exíguo, Que inviabilizava a concorrência, na modalidade de técnica e preço, para a aQuisição. Os dirigentes da unidade fizeram então ampla pesQuisa de preços e promoveram a compra mais vantajosa, com base no dispositivo Que autoriza a compra emergencial, sem licitação;

Achado em auditoria, o fato em procedimento normal levaria a imputação de multa, porque é inaplicável o instituto da emergência, Quando o fato é previsível, ou não está caracterizado risco à segurança de pessoas e bens, sejam públicos ou privados;

O corpo instrutivo, guardando coerência com a jurisprudência da Corte, informou o processo nesse sentido, mas o Ministro relator Valmir Campelo, adotou deliberação diversa, preferindo relevar a aplicação de multa em caráter excepcional, reconhecendo a vantaj̧osidade para o erário da aquisição procedida e recomendando ao órgão repassador que liberasse os recursos em tempo suficiente para Que as unidades pudessem dar cumprimento às formalidades legais prévias à realização da despesa. ${ }^{16}$

Tal episódio reforça a importância e o valor dos Tribunais de Contas como órgãos de controle, porque podem decidir além da legalidade, sempre Que necessário, para efetivar o comando da legitimidade e eficiência. Independentemente da causa ou do ardil utilizado para não transferir os recursos a destempo para sua utilização, a decisão atacou o ponto central do problema, a causa remota da ilegalidade praticada pelos dirigentes da Universidade. Providências nesse sentido devem passar a ser a regra no momento em Que a Lei de Responsabilidade Fiscal coloca em destaque a necessidade de estabelecer uma estrutura de custos e de avaliação de resultados.

Não só a legislação Que regula as finanças públicas como a Que rege as licitações e contratos administrativos obriga a análise de custos, mas a Lei de Responsabilidade Fiscal foi mais longe ao expressamente dispor sobre o dever da Lei de Diretrizes Orçamentárias estabelecer normas relativas ao controle de custos dos programas financiados com recursos orçamentários.

\footnotetext{
${ }^{56}$ FERNANDES, Jorge Ulisses jacobi. Contratação Direta sem Licitaçăo, Brasília Jurídica, 2000, p.320.
} 


\section{EXIGÊNCIAS LEGAIS}

A demonstração de Que a contratação direta foi a via adequada e efetiva para elidir o risco de dano ao interesse público não é suficiente para legitimar a atuação do administrador público. Deverá ser comprovada e documentada a presença dos ręuisitos legais que autorizam as contratações diretas, sujeitando o administrador público ao cumprimento das disposições da Lei n. ${ }^{\circ} 8.666 / 93$.

As contratações diretas, como regra geral, sujeitam-se ao cumprimento de alguns requisitos essenciais. A Lei de Licitações prevê para a hipótese do inciso IV, do art. 24, também, a comprovação da caracterizaçāo da situação emergencial ou calamitosa Que justifieue a dispensa.

Como regra geral, as hipóteses de licitação dispensada, previstas nos $\$ \S 2 .^{\circ} \mathrm{e} 4 .^{\circ} \mathrm{do}$ art. 17, as dispensas de licitação dos incisos III a XXIV do art. 24 e inexigibilidades do art. 25 serão necessariamente justificadas. A exigência nada mais é que o cumprimento do princípio da motivação consubstanciado no dever de o administrador público justificar seus atos, apontando-thes os fundamentos de direito e de fato, assim como a correlação lógica entre os eventos e situações Que deu por existentes e a providência tomada, nos casos em que este último aclaramento seja necessário para se aferir a consonância da conduta administrativa com a lei Que the serviu de arrimo.

No âmbito da Administração Pública Federal, a legalidade da contratação direta fica condicionada ao atendimento de outros requisitos exigidos como: a justificativa da contratação, autorização do Ordenador de Despesas para a contratação direta, descrição detalhada do objeto da contratação, orçamentos contendo os valores da contratação. comprovantes da regularidade fiscal da empresa contratada, declaração de Inexistência de Fato Impeditivo e declaração de cumprimento do disposto no inciso XXXIII do art. 7..$^{\circ}$, da Constituição Federal, previsão dos recursos financeiros Que assegurem o cumprimento da obrigação mediante Declaração do Ordenador de Despesas atestando a disponibilidade orçamentária e financeira para a contratação, segundo o inciso ll e $\$ 4 .^{\circ}$ do art. 16, da Lei Complemientar n. 101 , de 04 de maio de 2000 e art. 60 da n. ${ }^{\circ} 4.320$, de 17 de março de 1964, caracterização da situação emergencial ou calamitosa Que justifique a dispensa, razão da escolha do fornecedor ou executante, justificativa do preço, mediante a apresentação de orçamentos, minuta de contrato, Quando o caso exigir (art. 62, $§ 4 .^{\circ}$ ) e aprovação pela assessoria jurídica.

\subsection{Análise Jurídica nas Dispensas de Licitação}

No Que tange a esta última exigência, há entendimentos contrários à sua obrigatoriedade. A Lei Complementar n. ${ }^{\circ} 73$, de 10 de fevereiro de 1993, Que instituiu a Lei Orgânica da Advocacia-Geral da União, dispōe Que competem às Consultorias Jurídicas examinar prévia e conclusivamente os atos pelos Quais se reconhecerá a inexigibilidade ou se decidirá acerca da dispensa de licitação.

Em Qualquer processo de contratação, por exigência legal, a emissão do parecer é ato necessário para o regular andamento do processo. Sua finalidade é justamente garantir que a contratação obedeça às normas legais pertinentes. 
$\mathrm{O}$ inciso VI do art. 38 da Lei n. ${ }^{\circ} 8.666 / 93$ prevê que serão juntados ao processo licitatório os pareceres técnicos ou jurídicos emitidos sobre a licitação, dispensa e inexigibilidade. Se a licitação é a regra e a dispensa ou inexigibilidade a exceção, forçoso é reconhecer que o parecer jurídico é tão relevante Quanto o parecer técnico. Não obstante a norma legal fazer referência a "pareceres técnicos ou jurídicos", a juntada do parecer técnico ao procedimento licitatório não significa dizer que o parecer jurídico possa ser dispensado, ou vice-versa, visto Que um não pode nem deve excluir o outro, apesar da presença da conjunção "ou" ligando os dois termos.

A interpretação do parágrafo único do art. 38 da Lei de Licitações não pode ser restritiva, porque a contratação direta, indubitavelmente, deve merecer manifestaçẫo do órgão jurídico, por ser um ato necessário para o regular andamento do processo. Não seria concebível dar tratamento diferenciado para os casos de dispensa e de inexigibilidade, pois os atos que os antecedem, na essência, nada mais são Que um procedimento licitatório simplificado, objetivando a contratação da empresa Que oferecer a melhor proposta. Além do mais, a motivação desses atos está condicionada ao atendimento da lei e do direito, devendolhes, portanto, obediência.

Assim, o parecer, emanado pela assessoria jurídica, ainda Que não mencionado expressamente no ato decisório do administrador público, constitui a sua própria motivação; ele integra o ato administrativo como reQuisito formal, hoj̣e considerado essencial à validade do ato pela doutrina mais autorizada - tem por finalidade precípua, justamente, garantir à Administração Pública Que a contratação obedeça às normas regulamentares.

\section{VINCULAÇÕES À APLICABILIDADE DO INCISO IV DO ART. 24}

Jessé Torres Pereira fúnior ${ }^{17}$ leciona Que a par da definição Que vincula a emergência à urgência, o estatuto das licitações criou duas outras vinculações a razões objetivas de fato e de direito (motivos), reduzindo o espaço discricionário do administrador e sujeitando o ato de dispensa a impugnaçóes por vício de motivo ou desvio de finalidade, a saber: somente os bens necessários ao atendimento da emergência ou da calamidade poderão ser adquiridos sem licitação, o Que afasta a dispensa do certame para a contratação de Quaisquer outros objetos, ainda Que vigente a situação de emergência ou de calamidade; tratando-se de obras ou serviços, somente serão passíveis de aquisição direta aQueles cuja execução possa estar concluída em até 180 dias, consecutivos e ininterruptos, contados da emergência ou calamidade; de vez que estas podem prolongar-se, o termo a quo coincidirá com a data em que ocorreu o fato deflagrador da emergência ou da calamidade.

O doutrinador ensina Que muito se tem ponderado sobre exceçóes que devam ser admitidas ao aparente absolutismo do prazo de 180 dias, na doutrina e nos Tribunais de

\footnotetext{
"7 JúNioR, Jessé Torres Pereira. Comentários à Lei de Licitações da Administração Pública, Renovar, 2003, p.268
} 
Contas, de modo a reconhecer-se Que não é, nem poderia ser, absoluto, admitindo-se Que pode e deve ceder diante de circunstâncias incontornáveis pela Administração, sob pena de lesão ao interesse público.

\section{Extrai-se da Decisão n. ${ }^{0} 820 / 96^{18}$ - Plenário - o excerto:}

Diante do exposto, entendo, conclusivamente, Que os contratos, firmados com dispensa de licitação, com base no disposto no inciso IV, art. 24, da Lei $n^{\circ}$ $8.666 / 93$, embora tenham prazo máximo de 180 (cento e oitenta) dias para a conclusão das obras e serviços, podem ser prorrogados, desde Que ocorra, posteriormente, fato excepcional ou imprevisivel, estranho à vontade das partes, Que altere fundamentalmente as condições de execução do contrato.

\section{REGULARIDADE E LEGALIDADE DOS ATOS ADMINISTRATIVOS}

Os atos Que antecedem a contratação emergencial não recebem um tratamento diferenciado do procedimento licitatórío, pois a contratação direta não significa inaplicação dos princípios básicos Que orientam a atuação administrativa, nem se caracteriza uma livre atuação administrativa. $\mathrm{O}$ administrador está obrigado a seguir um procedimento administrativo determinado, destinado a assegurar a prevalência dos princípios jurídicos fundamentais aplićáveis à licitação. Permanece o dever de realizar a melhor contratação possível, dando tratamento igualitário a todos os possíveis contratantes.

A contratação direta não significa eliminação de dois postulados consagrados a propósito da licitação. O primeiro é a existência de um procedimento administrativo e o segundo é a prevalência dos princípios da supremacia e indisponibilidade do interesse público.

O art. 113 da Lei de Licitações deixa claro que as autoridades administrativas têm o dever de demonstrar a regularidade e a legalidade dos atos que praticam. Assim, a demonstração concreta e efetiva da potencialidade de dano, a demonstração concreta de que a contratação foi a via adequada e efetiva para elidir o risco são indispensáveis para caracterizar a hipótese de dispensa de licitação com base no inciso $\mathrm{N}$, do art. 24, assim como os demais requisitos exigidos por lei, notadamente aqueles elencados no art. 26 e seu parágrafo único.

Não obstante a situaçăo dada como de urgência permitir Que a contratação se dê na forma do inciso $\mathrm{N}$, afastando a possibilidade de dano ou prejuízos ao interesse público, a desídia do administrador ou falta de planejamento viola as normas gerais, sujeitando-o às sanções previstas na própria lei de licitações: "Art. 89. Dispensar ou inexigir licitação fora das hipóteses previstas em lei, ou deixar de observar as formalidades pertinentes à dispensa ou à inexigibilidade: Pena - detenção, de 3 (três) a 5 (cinco) anos, e multa."

\footnotetext{
${ }^{18}$ BRASli..Tribunal de Contas da Uniăo. Processo n. ${ }^{\circ}$ 500.296/1996 - 0. 1996.
} 
É o dolo, correspondendo ao conhecimento, pelo agente, de Que a dispensa de licitação efetiva-se em desacordo com a lei, ou, ainda Que não o seja, de que se as estão processando com menosprezo das formalidades Que a lei exige para tanto, tendo o agente a vontade livre de praticar as ações de acordo com a figura encartada no dispositivo.

Desta feita, o administrador deve ter muita cautela ao dispensar uma licitação, tendo em vista que o agente público será punido não somente Quando contratar diretamente sem amparo na previsão legal do inciso IV. do art. 24, mas, também, Quando deixar de observar as formalidades exigíveis para os processos de dispensa e inexigibilidade de licitação previstas no art. 26.

Jorge Ulisses Jacoby Fernandes ${ }^{19}$, afirma Que após a vigência deste dispositivo legal, há maior preocupação do Administrador Público nos processos relativos à dispensa e inexigibilidade de licitação, pois, efetivamente, o art. 89 da Lei $8.666 / 93$ situa-se na linha evolutiva do aperfeiçoamento da Administração Pública, não raro, as justificativas da contrataçāo direta eram elaboradas posteriormente à celebração do contrato, à sua execução e, às vezes, só após a açâo dos órgãos de controle, onde passavam a desafiar a criatividade dos órgãos jurídicos das entidades públicas.

O fato é Que, com o advento desse diploma legal, passou a haver maior preocupação com os procedimentos que devem ser adotados para que a contratação direta seja considerada regular.

De outro modo, é evidente Que se o fornecedor ou prestador de serviços concorrer para a ilegalidade também deverá ser aplicada pena semelhante à atribuída ao administrador.

\section{CONSIDERAÇÕES FINAIS}

A emergência pode ser caracterizada pela inadeouação do procedimento formal licitatório ao caso concreto. Mais especificamente: um caso é de emergência Quando reclama solução imediata, de tal modo que a realização da licitação, com os prazos e formalidades que a lei exige, pode causar prejuízo (obvamente prejuízo relevante) ou comprometer a segurança de pessoas, obras, serviços ou bens, ou ainda, provocar a paralisaçăo ou prejudicar a regularidade das atividades específicas do órgão público.

O Tribunal de Contas da União entende que são pressupostos da aplicação do caso de dispensa de licitação preconizado no art. 24 , inciso IV, da Lei $n .{ }^{\circ} 8.666 / 93$, Que a situação adversa, dada como de emergência ou de calamidade pública, não se tenha originado, total ou parcialmente, da Falla de planejamento, da desídia administrativa ou da má gestão dos recursos disponíveis, ou seja, Que ela não possa, em alguma medida, ser atribuída à culpa ou dolo do

\footnotetext{
${ }^{19}$ FERNANDES, jorge Ulisses Jacobi. Contratação Direta sem Licitaçäo, Brasilia lurídica, 2004, p.624.
} 
agente público Que tinha o dever de agir para prevenir a ocorrência de tal situação. Que exista urgência concreta e efetiva do atendimento à situação decorrente do estado emergencial ou calamitoso, visando afastar risco de danos a bens ou à saúde ou à vida de pessoas. Que o risco, além de concreto e efetivamente provável, se mostre iminente e especialmente gravoso e que a imediata efetivação, por meio de contratação com terceiro, de determinadas obras, serviços ou compras, segundo as especificações e Quantitativos tecnicamente apurados, seja o meio adequado, efetivo e eficiente de afastar o risco iminente detectado.

Independente de culpa do administrador público pela não realização do procedimento licitatório na época oportuna, a caracterizar a desídia administrativa, se estiverem presentes todos os requisitos previstos no dispositivo, mesmo assim, cabe dispensa de licitação, segundo julgados do próprio Tribunal de Contas da União. A inércia do administrador, dolosa ou culposa, não pode vir em prejuízo do interesse público maior a ser tutelado pela Administração, não eximindo o agente que deu causa à situação de urgência de ser responsabilizado.

Tema polêmico diz respeito à contratação direta com base no art. 24, inciso IV, em face da descentralização de recursos financeiros ao final do exercício, conjugada com a impossibilidade de conclusão do procedimento licitatório em tempo hábil. A possibilidade de contratação direta com fulcro no inciso $N$ encontra supedâneo no direito constitucional traduzido na necessidade de os órgãos públicos conduzirem, planificarem e conformarem suas atuações com a proteção da confiança mútua, a par da demonstração do interesse público a ser tutelado pela administração, da necessidade do objeto a ser contratado e da demonstração de Que a ausência de contratação poderá provocar a paralisação ou prejudicar a regularidade de suas atividades específicas.

A contratação direta na forma do inciso N, do art. 24, sujeitará o administrador público ao cumprimento das disposições da Lei n. ${ }^{\circ} 8.666 / 93$, notadamente as do art. 26 , com a comprovação e documentação da presença dos requisitos legais exigíveis. A Lei de Licitações deixa claro o dever de as autoridades administrativas demonstrar a regularidade dos atos oue praticam.

\section{REFERÊNCIAS BIBLIOGRÁFICAS}

AMARAL, Antônio Carlos Cintra do. Licitação para Concessão de Serviço Público. São Paulo:Malheiros. 1995.

BONAVDES, Paulo. Curso de Direito Constitucional. São Paulo: Matheiros, 2004.

BRASIL. Constituição Federal, de 05 de outubro de 1988. Obtido em: wuw.planalto gov.br. Acessado em 29 de Março de 2005. Última atualização não disponivel.

. Lei de Diretrizes Orçamentátias n. ${ }^{\circ}$ 10.934, de II de agosto de 2004. Obtido em: www. planalto.gov.br. Acessado em 29 de Março de 2005. última atualização não disponivel.

Lei n. ${ }^{\circ} 8.666$, de 21 de junho de 1993. Obtido em: www.planalto.gov.br. Acessado em 29 de Março de 2005. última atualização não disponível. 
. Lei n. 4.401 , de 10 de setembro de 1964. Obtido em: www. planalto.gov.br. Acessado em 29 de Março de 2005 . Última atualização não disponível.

. Decreto-lei n. ${ }^{\circ} 200$, de 25 de fevereiro de 1967 . Obtido em: www.planalto gov.br. Acessado em 29 de Março de 2005. Última atualização não disponivel.

. Decreto-lei 2.300, de 2 i de novembro de 1986. Obtido em: www.planatto.gov.br. Acessado em 29 de Março de 2005. Última atualização não disponivel.

. Leis n. 8.987 , de 13 de fevereiro de 1995. Obtido em: www.planalto gov.br. Acessado em 29 de Março de 2005. Última atualização não disponível.

Lei n. ${ }^{\circ} .074$, de 07 de julho de 1995. Obtido em: www.planalto.gov.br. Acessado em 29 de Março de 2005 . última atualização não disponivel.

. Lei n. 9.491, de 09 de setembro de 1997. Obtido em: www.planaito.gov.br. Acessado em 29 de Março de 2005. Última atualização não disponivel.

Lei n. ${ }^{\circ}$ 9.637, de I 5 de maio de 1998. Obtido em: www. planalto gov.br. Acessado em 29 de Março de 2005 . última atualização não disponível.

. Lei n. ${ }^{\circ} 9.649$, de 27 de maio de 1998. Obtido em: www.planalto.gov.br. Acessado em 29 de Março de 2005 . Útitma atualização não disponivel.

. Lei n. ${ }^{9} 9.790$, de 23 de março de 1999. Obtido em: www. planalto gov.br. Acessado em 29 de Março de 2005 . última atualização não disponível.

Lei n. ${ }^{0}$ 4.320, de 17 de março de [964. Obtido em: www.planalto.gov.br. Acessado em 29 de Março de 2005 . Última atualização não disponível.

. Lei Complementar n. ${ }^{\circ} 101$, de 04 de maio de 2000 . Obtido em: uww.planalto.govbr. Acessado em 29 de Março de 2005. Última atualização não disponivel.

- Lei Complementar n. ${ }^{\circ} 73$, de 10 de fevereiro de 1993. Obtido em:www. planalto.gov.br Acessado em 29 de Março de 2005. Úitima atualização não disponivel. 1989.

CAETANO, Marcelo. Princípios Fundamentais do Direito Administrativo. Rio de laneiro: Forense,

CANOTILHO, I.f Gomes. Direito Constitucional e Teoria da Constituição. Editor Livraria Almedina, 7a Edição.

CARVALHO FiLHO, josé dos Santos. As novas linhas do regime das licitaçōes. Instituto de Estudos Jurídicos, 1991.

DI PIETRO, Maria Sylvia Zanella. Temas Polêmicos sobre Licitações e Contratos. São Paulo: Makheiros Editores, 2. ${ }^{\mathrm{a}}$ Edição. 1993.

ESCOBAR, J. C. Mariense. Licitação, Teoria e Prática. Porto Alegre: Livraria do Advogado.

FERNANDES, Jorge Ulisses Jacobi. Contratação Direta sem Licitação. Brasilia Jurídica, 5. ${ }^{a}$ Edição.

FIGUEIREDO, Lúcia Valle e Sérgio Ferraz. Dispensa e Inexigibilidade de Licitação. Editora Revista dos Tribunais, 2. Edição. 
GASPARINI, Diógenes. Direito Administrativo. São Paulo: Saraiva, 1992. 2a edição.

JÚNIOR, Cretella. Das Licitaçôes Públicas. 3 .a Edição, 1993.

Dialética, 2002.

JUSTEN Filho, Marçal. Comentários à Lei de Licitações e Contratos Administrativos. São Paulo:

MELLO. Celso Antônio Bandeira de. Curso de Direito Adninistrativo. São Paulo: Malheiros.

MENDES, Gilmar Ferreira. Controle de Constitucionalidade: aspectos jurídicos e politicos. São Paulo: Saraiva. 1990.

PEREIRA JÚNIOR, lessé Torres. Comentários à Lei de Licitações da Administração Públílca. São Paulo: Renovar, 6 . Edição.

STERN, Klaus. Derecho del Estado de la Republica Federal Alemanha. Madrid: Centro de Estudios Constitucionales, 1987. Colección Estudios Constitucionales.

TRIBUNAL DE CONTAS DA UNIÃO. Plenário. Decisão 347/1994, Número Interno do Documento DC-0347-22/94-P, Processo 009.248/1994-3.

0272-2 [//02-2, Processo 006.932/1995-9.

Processo 007.585/1999-7.

P. Processo 500.296/1996-0.

. Decisão 820/1 996. Plenário. Número Interno do Documento DC-0820-5 I/96

. Decisão 524/1999. Plenário. Número Interno do Documento DC-0524 35/99-P.

Processo 926.268/98-8.

. Acórdão 1204/2004. Primeira Câmała. Número Interno do Documento AC[ 204- [ 6/04-1. Processo 014.789/2002-3.

Processo 017.455/200-6.

Acórdão 383/2003. Plenário. Número Interno do Documento AC-083-13/03-P.

. Acórdão 1490/2003. Segunda Câmara. Número Interno do Documento AC1490- 32/03-2. Processo 016.304/1995-0.

. Acórdão 348/2003. Segunda Câmara. Número Interno do Documento AC0348-08/03-2. Processo 018.598/2002-0.

. Acórdáo 282/2002. Segunda Câmara. Número Interno do Documento AC-

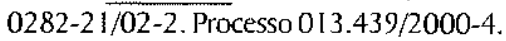

. Acórdão 376/1999. Segunda Câmara. Número Interno do Documento AC0376-29/99-2. Processo 012.740/1994-2.

P. Processo 575.144/1997-1.

Acórdão 343/2002. Plenário. Número Interno do Documento AC-0243-23/02-

. Acórdão 399/2002. Plenário. Número Interno do Documento AC-0299-30/02-

P. Processo 004.646/1999-1. 